\title{
AUSTROPOTAMOBIUS TORRENTIUM AS AN INDICATOR FOR HABITAT QUALITY IN RUNNING WATERS?
}

\author{
M. PÖCKL (1), F. STREISSL (2)
}

(1) Vienna Ecology Center, Department of Freshwater Ecology, University of Vienna; and State Government of Lower Austria, Experts for the Conservation of Nature, Landhausplatz 1, A-3109 St. Pölten, Austria.

E-Mail: Manfred.Poeck।@noel.gv.at

(2) Sturzgasse 25/1/7, 1150 Wien, Austria.

E-mail: Franz.Streissl@ages.at

Reçu le 9 novembre 2004

Accepté le 4 janvier 2005

Received November 9, 2004

Accepted January 4, 2005

\begin{abstract}
In the present study we tried to quantify the indication value of $A$. torrentium referring to habitat quality. This variable is expressed as the availability of appropriate refuge stones on the bottom and banks of running waters. The brooks occupied by the indigenous stone crayfish in Lower Austria show a high variability in the current velocity and substrate heterogeneity. Having some experience in hand searching we assumed that the distribution pattern of the crayfish on the stream bed is strongly correlated with the distribution of cobble and pebbles within a certain grain size. The aim of our study was to quantify the dependence of the shelter requirements for $A$. torrentium on grain size and water velocity, as well as the seasonal mobility of the crayfish. Shelters where velocity exceeded $25 \mathrm{~cm} \mathrm{~s}^{-1}$ were not occupied. Pebbles with a bearing surface greater than $300 \mathrm{~cm}^{2}$ were preferred, and the probability of crayfish occupation rose quickly as the stone's bearing surface increased up to $900 \mathrm{~cm}^{2}$. Most individuals changed their location only a few meters (median $4 \mathrm{~m}$ ). The distance from the point of first capture increased only little within the length of time passed until re-capture, suggesting a conservative use of space.
\end{abstract}

Key-words: Austropotamobius torrentium, substrate heterogeneity, shelter requirements, seasonal mobility, number of crayfish outside shelters, sexual ratio.

\section{AUSTROPOTAMOBIUS TORRENTIUM EST-ELLE UN INDICATEUR DE LA QUALITÉ DES HABITATS DANS LES EAUX COURANTES ?}

\section{RÉSUMÉ}

La présente étude tente de quantifier la valeur indicative de $A$. torrentium par rapport à la qualité de l'habitat. Cette variable s'exprime en disponibilité en pierres servant d'abris dans le fond et les berges des rivières. Les ruisseaux occupés par des écrevisses des torrents autochtones en Basse Autriche montrent une grande variabilité de la vélocité du courant et de l'hétérogénéité du substrat. Ayant quelque expérience de la collecte manuelle, nous avons supposé que la distribution des écrevisses dans le lit du courant est fortement corrélée à celle des galets et des cailloux d'une certaine granulométrie. 
Le but de notre étude était de quantifier la dépendance des besoins en refuges pour A. torrentium en fonction de la granulométrie et de la vitesse du courant, ainsi que de la mobilité saisonnière des écrevisses. Les refuges où la vitesse du courant est supérieure à $25 \mathrm{~cm} \cdot \mathrm{s}^{-1}$ ne sont pas occupés. Les galets dont la surface d'appui dépasse les $300 \mathrm{~cm}^{2}$ sont préférés, et la probabilité d'occupation augmente rapidement avec la surface d'appui des pierres, jusqu'à $900 \mathrm{~cm}^{2}$. La plupart des individus se déplacent seulement de quelques mètres (médiane $4 \mathrm{~m}$ ). La distance entre le point de première capture et la recapture augmente peu lorsque l'intervalle de temps entre les captures augmente, ce qui suggère une utilisation conservatrice de l'espace.

Mots-clés : Austropotamobius torrentium, hétérogénéité du substrat, exigences en abris, mobilité saisonnière, nombre d'écrevisses hors de leurs abris, sex-ratio.

\section{INTRODUCTION}

Knowledge and understanding of the habitat preference is essential for effective management and conservation measures of endangered species. Like other indigenous crayfish species, Astacus astacus (Linnaeus, 1758) and Austropotamobius pallipes (Lereboullet, 1858), the stone crayfish Austropotamobius torrentium (Schrank, 1803) is threatened (e.g. BOHL, 1989; TROSCHEL and DEHUS, 1993; PÖCKL, 1999, 2002). In the national Red Data Book of Animals in Austria it is listed under the category "endangered" (PRETZMANN, 1994). The stone crayfish occurs in the upper tributaries of the Rhine River in Germany and Switzerland and in the Danube catchment, from the headwaters to the Iron Door. The territory of $A$. torrentium extends from $50^{\circ} \mathrm{N}$ in Germany to $41^{\circ} \mathrm{N}$ in Macedonia and $8^{\circ} \mathrm{E}$ at the Rhine to about $24^{\circ} \mathrm{E}$ in Romania (LAURENT, 1988). MACHINO and FÜREDER, 2005, found the stone crayfish in Greece and the European part of Turkey. Austropotamobius torrentium inhabits high gradient small brooks characterised by heterogeneous flow patterns (WINTERSTEIGER, 1985; BOHL, 1989; GAMPERL, 1990; STREISSL, 2002). A close relationship exists between stream morphology, substrate and abundance of many crayfish species (e.g. PAYNE, 1984; BOHL, 1989; FOSTER, 1990; EVERSOLE and FOLTZ, 1993; TROSCHEL, 1997). Highest densities of Astacus astacus occurred in gravel and stony areas (NIEMI, 1977). To sustain a population the substrate must provide appropriate shelter to afford the crayfish protection from predation and to prevent drift. Substrate composition also influences locomotory activity patterns of crayfish (KLOSTERMAN and GOLDMAN, 1981; WESTIN and GYDEMO, 1988; WHALE and STERNECK, 1992; JORDAN, DE LEON and MC CREARY, 1996). SCHULZ and KIRCHLEHNER (1984) showed that $A$. torrentium abundance was correlated to the relative amount of stones and pieces of wood, serving as shelter for this crayfish. DEMERS, REYNOLDS and CIONI, (2004) investigated habitat preference of different size classes of A. pallipes in an Irish River. Whereas adult crayfish occur under stones and cobble in the river, smaller individuals may be found along the margins, among rootlets and vegetation (SMITH et al., 1996; REYJOL and ROQUEPLO, 2002).

Crayfish, especially non-indigenous species, are known to be very mobile, wander huge distances and are thus able to colonise new territories. BUBB, THOM and LUCAS, 2005 , studied the within-catchment colonisation and expansion of the signal crayfish (Pacifastacus leniusculus). Range expansion of up to $2.4 \mathrm{~km}_{\text {year }}{ }^{1}$ was recorded from an established population, but rates over an order of magnitude less were recorded in the initial stages of establishment. The seasonal mobility behaviour of stone crayfish populations has not been studied before, but a better knowledge how this endangered indigenous crayfish species uses its habitat in space and time and which distances it covers is another important piece in the puzzle of information necessary for conservation management. Active mobility allows large invertebrates to optimally forage spatially and temporarily limited resources, to find mates for reproduction and to (re-) colonize appropriate habitats. 
The purpose of the present study was to identify those factors responsible for making shelters attractive for this species. In addition, we quantified the relationship between crayfish body size and refuge size in the natural environment of $A$. torrentium in Lower Austria. Another goal was to investigate the seasonal mobility and distances covered by individual stone crayfish.

\section{MATERIAL AND METHODS}

\section{Sudy area - the Biberbach}

The Biberbach (engl.: "Beaver Creek") is located at the northern border of the Alpine flysh-zone at a sub-montane altitude (ELLENBERG, 1986) of 340-370 m a.s.l. It is situated at $48^{\circ} 00^{\prime} \mathrm{N}$ and $14^{\circ} 42^{\prime} \mathrm{E}$ (Figure 1). The substrate consisted predominantly of sandstone and marl. The studied section had a length of $106 \mathrm{~m}$, and the width of the river varied between 1.6 and $5.2 \mathrm{~m}$. Water velocity which was measured $2 \mathrm{~cm}$ above the ground using an Impeller meter averaged between 12 and $18 \mathrm{~cm} \mathrm{~s}^{-1}(n=585)$. Water temperatures ranged from $1^{\circ} \mathrm{C}$ in winter to a maximum of $20^{\circ} \mathrm{C}$ in summer. The substrate of the river bed was composed as follows: a) cobble with a grain size of more than $20 \mathrm{~cm}(17 \%)$, b) pebbles with a grain size from 5 to $20 \mathrm{~cm}(48 \%)$, c) stones with a grain size from 0.5 to $5 \mathrm{~cm}(32 \%)$, d) sand, being defined as particles less than $0.5 \mathrm{~cm}(1 \%)$, e) larger particulate organic matter, such as leaf litter, blossoms, seeds, wood (2\%). Thus, category a) and b) taken together compose $65 \%$ of the substrate. The following chemical variables were measured monthly using a $\mathrm{pH}$-meter and test kits. The following ranges of values are given: $\mathrm{pH}, 7.60-8.56$; dissolved oxygen, 8.5-10.6 $\mathrm{mg} \mathrm{l}^{-1}$; oxygen saturation, 77-93\%; total hardness, 133-152 $\mathrm{mg} \mathrm{l}^{-1}$, and carbonate hardness, 116-132 $\mathrm{mg} \mathrm{l}^{-1}$.

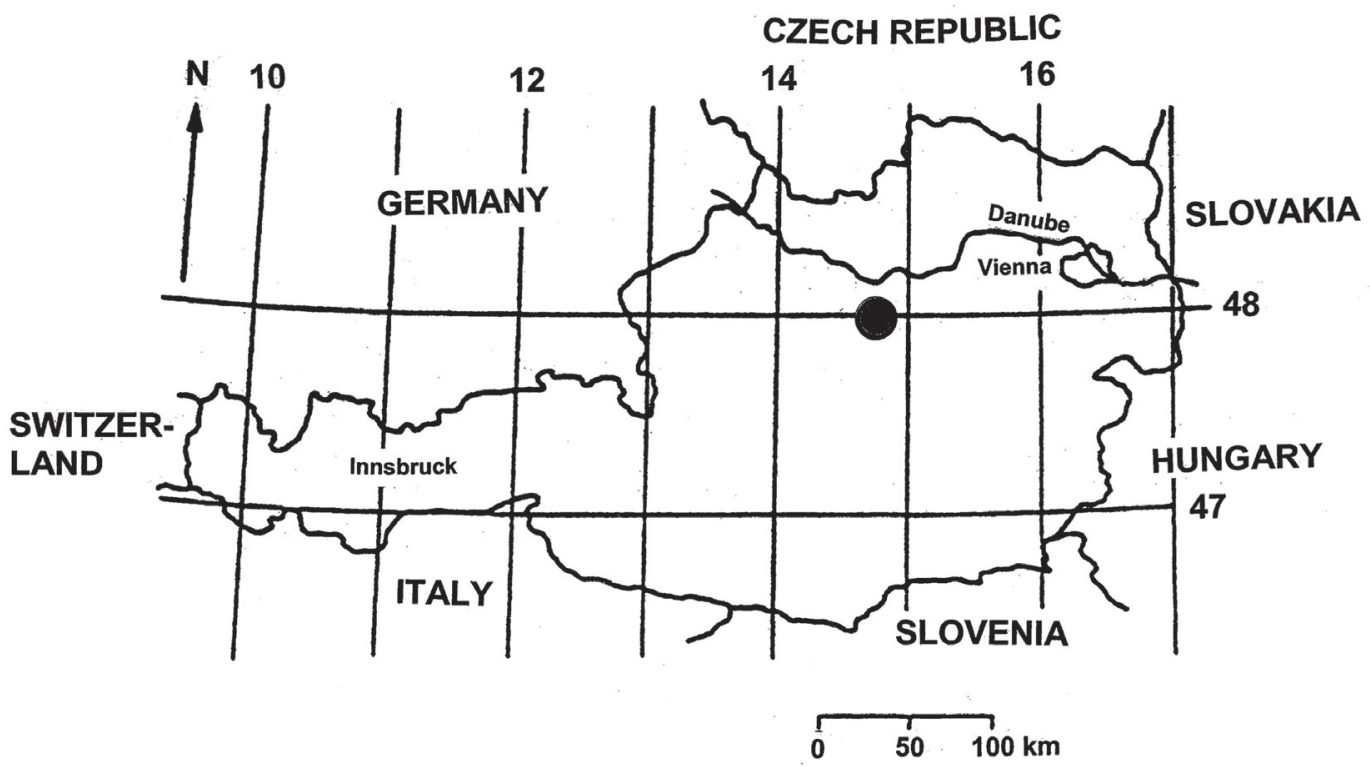

Figure 1

Map showing the geographical position of the study stretch in the Biberbach (engl. "Beaver Creek") in Lower Austria.

\section{Figure 1}

Carte de localisation géographique du secteur étudié du Biberbach (engl. "Beaver Creek») en Basse Autriche. 


\section{Sampling Methods}

Individual $A$. torrentium were caught by stone turning over a total of 12 days in April, June and August 1997. Captured specimens were weighed and sexed. Total length $(T L)$, carapace length $(C L)$, carapace width $(C W)$ and chela length $(C H L)$, chela width (CHW), and chela depth (CHD) were measured to the nearest mm using vernier callipers. From each stone that was turned, the length (SL), width (SW), height $(\mathrm{SH})$ and the water depth (D) from the substrate underneath the stone to the water surface were measured. The area (SA) of a stone facing to the substrate was estimated from the relationship: $\mathrm{SA}\left(\mathrm{cm}^{2}\right)=\mathrm{SL}$ * SW and the approximate volume (SV) of a stone was calculated from: $\mathrm{SV}\left(\mathrm{cm}^{3}\right)=\mathrm{SL}$ * SW * $\mathrm{SH}$. In order not to alter the crayfish habitat each stone was put back to its original position.

Because of the non-normally distribution of variables, bivariate correlation analysis (Spearman - rank) and regression analysis were used to detect relations between crayfish size and the size of the stones used as shelters.

In summer 1998, a presence/absence study was conducted to identify those variables influencing crayfish use of shelters. Five stones selected by chance, larger than $3 \mathrm{~cm}$ in diameter, per randomly chosen square meter were examined for occurrence of crayfish. Randomness was achieved by using random numbers to select square meters in the mapped study sections. Stone variables and water depth were measured as described above. Stream velocity (V) was measured using an Impeller-meter (Ott-C2) $4 \mathrm{~cm}$ above the substratum at the location of the removed stone. Logistic regression (HOSMER and LEMESHOW, 1989) was used for statistical analysis.

A prerequisite for the mobility studies was the individual recognition of the specimens. The individual marking was accomplished using the method of ABRAHAMSSON (1965). 734 specimens of $A$. torrentium were marked individually by burning dots into the carapace at special positions (Figure 2) using a soldering iron. The advantage of this method was that the markings could also be identified even after moulting, the disadvantage was that only specimens with a total body length exceeding $35 \mathrm{~mm}$ could be used because mortality was noticed to be significant for smaller animals during a laboratory test of the method (PÖCKL unpublished data). The movement of $A$. torrentium was studied in the Biberbach from August 1997 to September 1998.

The spatial position of the marked crayfish was noticed in special mapping records. Grid numbers were used to identify the exact position. The distribution of the stones on the bed of the river over the total study area (106 m long, 1.6-5.2 $\mathrm{m}$ wide) was photographed from above and the photos were put together. By tracing each of the photos on a sheet of paper, a reduced map (scale 1:10) of the study stretch was produced. Grids of $1 \mathrm{~m} \times 1 \mathrm{~m}$ were identified and marked from $A$ to $F$ and 1 to 106 . After a time interval of 2 weeks marked specimens were re-captured during noctural observations, but also when a marked specimen was noticed during daytime outside its refuge the exact position was noticed. Hence, it was possible to determine individual distances covered by the crayfish. Nocturnal observations started after dawn, and the time spent was 4 minutes per $10 \mathrm{~m}^{2}$ (not counting the time for handling, measuring and recording). In order to compare the distances covered by the animals between sex, size, season and direction of the movement (upstream or downstream), Man-Whitney-U-tests were accomplished at a significance level of $5 \%(P<0.05)$.

\section{RESULTS}

Analysis of ratios (Table I) indicated that stones used as shelters were at least 3 times longer, 1.3 times wider and 1/4 times higher than the carapace length of the stone crayfish. The stones bearing surface was 6.5 times larger than the square of the carapace 


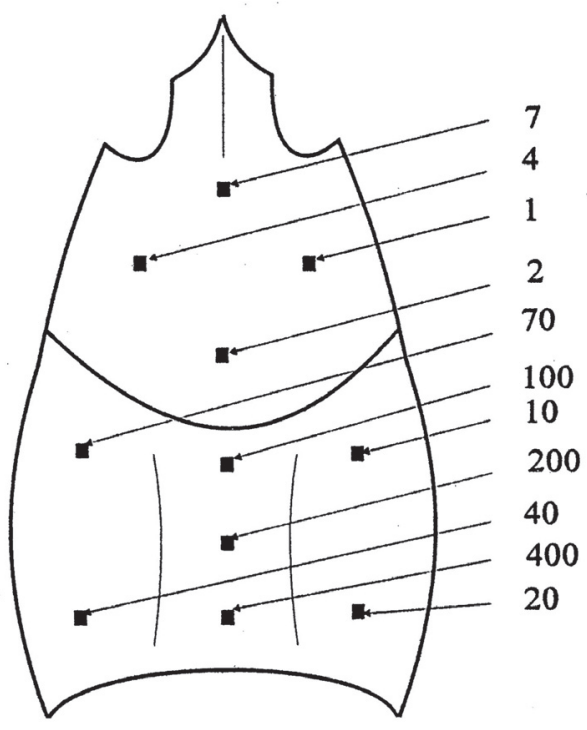

Figure 2

Carapace of $A$. torrentium showing the location of the individual marking dots. A numerical code was used by burning dots at special positions into the carapace. By combining the individual position of the dots it is possible to mark up to 799 specimens individually and thus to identify them without doubts when recaptured.

Figure 2

Carapace d'A. torrentium localisant les marques sur les individus. Un code numérique a été utilisé, par brûlure à des positions précises sur la carapace. En combinant les positions des points, il est possible de marquer plus de 799 spécimens individuellement afin de les identifier sans doute possible à la recapture.

Table I

Ratios of stone length (SL), width (SW), height (SH) and carapace length (CL) of the stone crayfish (A. torrentium) in the Biberbach, Lower Austria, $n=378$.

\section{Tableau I}

Ratios des longueurs (SL), largeurs (SW) et hauteurs (SH) des pierres et des longueurs des carapaces (CL) des écrevisses des torrents dans le Bilberbach, Basse-Autriche, $n=378$.

\begin{tabular}{|l|c|c|c|}
\hline & SL:CL & SW:CL & SD:CL \\
\hline Minimum & 3.19 & 1.25 & 0.25 \\
\hline Maximum & 93.22 & 55.88 & 17.21 \\
\hline 25\% Percentile & 6.33 & 4.12 & 1.53 \\
\hline MEDIAN & 8.68 & 5.96 & 2.48 \\
\hline 75-\% Percentile & 11.98 & 8.15 & 4.09 \\
\hline
\end{tabular}


length. The median of the refuge size was 8.7 times longer, 6 times wider and 2.5 times higher than the length of the carapace. The median stone area was 50 times the square of the median carapace length $(n=378)$.

Male crayfish body size was positively correlated to stone size variables (Table II). The strongest correlations were between crayfish size and stone width, and between crayfish size and stone area. No correlation between the size of female crayfish and the stone size was found. Neither male nor female body size was correlated to water depth at the refuge locality.

If all measured shelter variables (SL, SW, SH, D, V) were included in the logistic regression model $58 \%$ of the stones with a crayfish occupant and $97 \%$ of the stones without a crayfish occupant were correctly classified. The goodness of fit was characterised by -2LL using the "log likelihood-method" (HOSMER and LEMESHOW, 1989). -2LL decreased high significantly from 512.07 (model containing only the constant) to 257.3. Stone height $(\mathrm{SH})$ and water depth $(\mathrm{D})$ were insignificant shelter variables, because their partial correlations were 0 and the Wald Statistic showed that their coefficients were not significantly different from 0 (Table III).

Water velocity, stone width and, additionally, stone area facing the ground were analysed separately. At a water velocity of $0-5 \mathrm{~cm} \mathrm{~s}^{-1}$ the probability of crayfish occupancy was almost $40 \%$. The probability of crayfish presence decreased rapidly with increasing water velocity and approximated zero for velocities higher than $25 \mathrm{~cm} \mathrm{~s}^{-1}$ (Figure 3). The

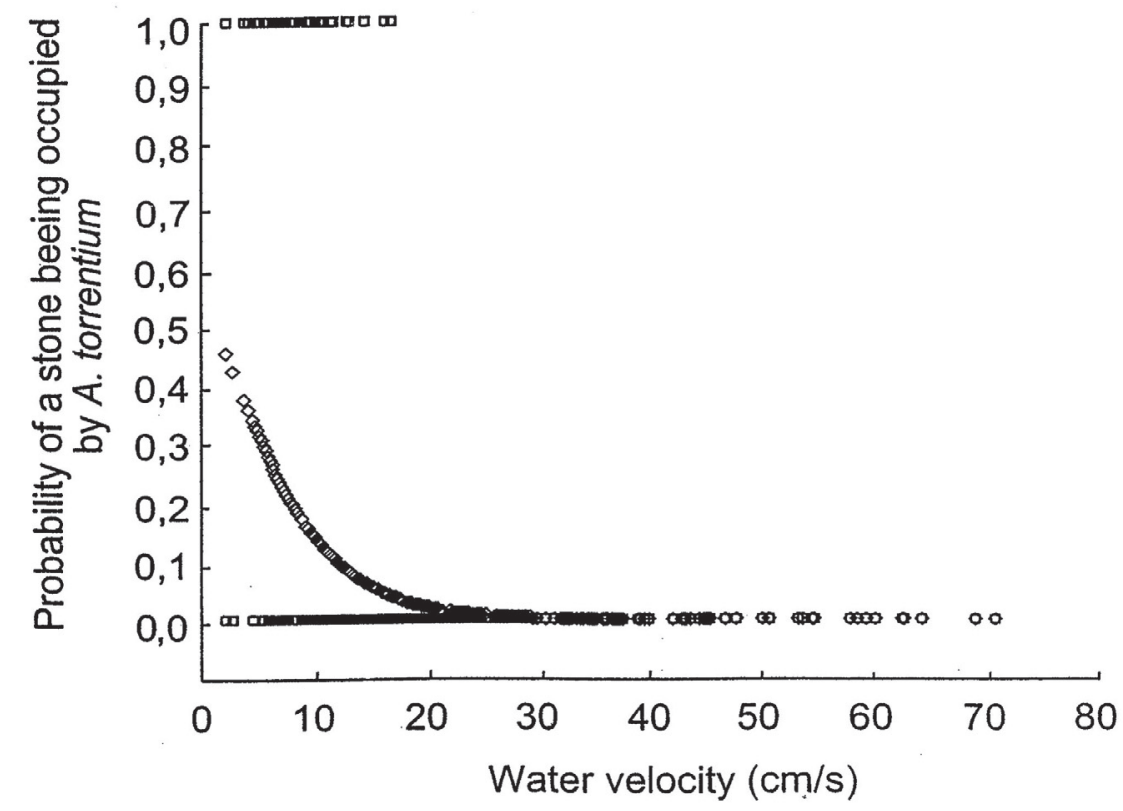

Figure 3

Logistic regression analysis of stone crayfish presence/absence underneath a stone dependent on water velocity $(V)$ at the location of the stone crayfish in the Biberbach, Lower Austria. Probability of crayfish presence $=1 / 1+e^{-\left(0.2259+0.2026^{*} \mathrm{~V}\right)}$. Calculated probabilities $=\diamond$; observed cases $=\square(n=584)$.

\section{Figure 3}

Analyse de régression par absence/présence des écrevisses des torrents sous une pierre et en fonction de la vitesse du courant (V) au point de localisation des écrevisses des torrents dans le Biberbach, Basse Autriche. Probabilité de présence des écrevisses $\left.=1 / 1+e^{-\left(0,2259+0,2026^{\star}\right.} \mathrm{V}\right)$. Probabilités calculées $=\downarrow ;$ Cas observés $=\square(n=584)$. 
Table II

Correlation coefficients of $A$. torrentium size and stone size in the Biberbach, Lower Austria. Correlation coefficients according to Spearman. Carapace length (CL), stone length (SL), stone width (SW), stone height (SH), water depth (D). Male (M), $n=167$, female (F), $n=186$.

Tableau II

Coefficients de corrélation entre la taille d'A. torrentium et la taille des pierres dans le Bilberbach, Basse-Autriche. Coefficients de corrélation d'après Spearman. Longueur de la carapace (CL), longueur des pierres (SL), largeur des pierres (SW), hauteur des pierres (SH), profondeur de l'eau (D). Mâles (M), $n=167$, femelle (F), $n=186$.

\begin{tabular}{|l|l|l|l|l|l|}
\hline & Sex & SL & SW & SH & D \\
\hline & & & & & \\
\hline CL & M & $0.286^{* *}$ & $0.334^{\star *}$ & $0.184^{*}$ & 0.079 \\
\hline & F & 0.087 & 0.086 & 0.086 & 0.045 \\
\hline
\end{tabular}

${ }^{*} P<0.05,{ }^{* *} P<0.01$ (Spearman correlation coefficient).

Table III

Logistic regression analysis (HOSMER and LEMESHOW, 1989) of the shelter variables: stone length (SL), stone width (SW), stone height (SH), water depth (D), and water velocity $(\mathrm{V})$ to predict $A$. torrentium presence underneath stones in the Biberbach, Lower Austria.

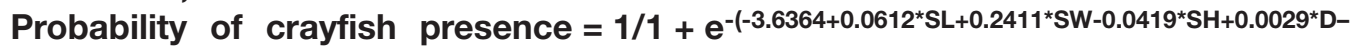
$\left.0.1994^{*} \mathrm{~V}\right), n=584$, Const. $=$ constant, $B=$ regression coefficient, $S . E .=$ standard error of coefficient, Wald = square of the ratio of the coefficient to its standard error, $\mathrm{df}=$ degree of freedom, $\mathrm{Sig}=$ level of significance $(P), \mathrm{R}=$ partial correlation (partial contribution of the variable to the model), $\operatorname{Exp}(B)=$ change of odds by increasing the value of the variable by one unit.

Tableau III

Analyse de régression (HOSMER and LEMESHOW, 1989) des variables d'abris: longueur des pierres (SL), largeur des pierres (WL), profondeur de l'eau (D), et vitesse de l'eau (V), pour prédire la présence d'A. torrentium sous une pierre dans le Biberbach, Basse-Autriche.

Probabilité de présence des écrevisses $=1 / 1+\mathrm{e}^{-\left(-3,6364+0,0612^{*} \mathrm{SL}+0,2411^{\star} \mathrm{SW}-\right.}$ $\left.0,0419^{*} \mathrm{SH}+0,0029^{*} \mathrm{D}-0,1994^{*} \mathrm{~V}\right), n=584$, Const. = constant, $\mathrm{B}=$ coefficient de régression, S.E. $=$ erreur standard du coefficient, Wald $=$ carré du ratio du coefficient par son écart-type, $\mathrm{df}=$ degré de liberté, $\mathrm{Sig}=$ significativité $(P), \mathrm{R}=$ corrélation partielle (contribution partielle de la variable au modèle), $\operatorname{Exp}(B)=$ résultats observés en augmentant la valeur de la variable d'une unité.

\begin{tabular}{|l|c|c|c|c|c|c|c|}
\hline & B & S.E. & Wald & df & Sig & $\boldsymbol{R}$ & Exp (B) \\
\hline SL & 0.0612 & 0.0309 & 3.9263 & 1 & 0.0475 & 0.0613 & 1.0631 \\
\hline SW & 0.2411 & 0.0470 & 26.3050 & 1 & 0.0000 & 0.2179 & 1.2726 \\
\hline SH & -0.0419 & 0.0475 & 0.7800 & 1 & 0.3771 & 0.0000 & 0.9589 \\
\hline D & 0.0029 & 0.0285 & 0.0102 & 1 & 0.9197 & 0.0000 & 1.0029 \\
\hline V & -0.1994 & 0.0313 & 40.5640 & 1 & 0.0000 & -0.2744 & 0.8192 \\
\hline Const & -3.6364 & 0.5668 & 41.1557 & 1 & 0.0000 & & \\
\hline
\end{tabular}


probability of crayfish occurrence was under $10 \%$ when the stone surface was less than $200 \mathrm{~cm}^{2}$. The presence probability rose quickly for stone areas larger than $300 \mathrm{~cm}^{2}$ and reached the value of $50 \%$ for $500 \mathrm{~cm}^{2}$. The curve flattened at a stone area of $900 \mathrm{~cm}^{2}$ (Figure 4). The probability of crayfish occurrence was less than $10 \%$ for stone widths smaller than $10 \mathrm{~cm}$. The probability curve of crayfish presence rose quickly for stones wider than $13 \mathrm{~cm}$ and approached $100 \%$ at a stone width of $25 \mathrm{~cm}$ (Figure 5).

The majority of the crayfish changed their location only a few meters (median 4 meters). Just a few crayfish shifted their location more than 55 meters within a time interval of 24 hours. The mobility between males and females did not differ significantly $(P=0,360)$.

The distances covered by individuals of $A$. torrentium within 1-3 days decreased successively from April, June and August (Figure 6). In April, the stone crayfish individually marked wandered significantly longer distances than in August. The median for June was between that for April and August, respectively.

A larger number of males were found upstream $(n=105)$ than downstream $(n=78)$ their last position, whereas females did not show a preferred direction of movement: 85

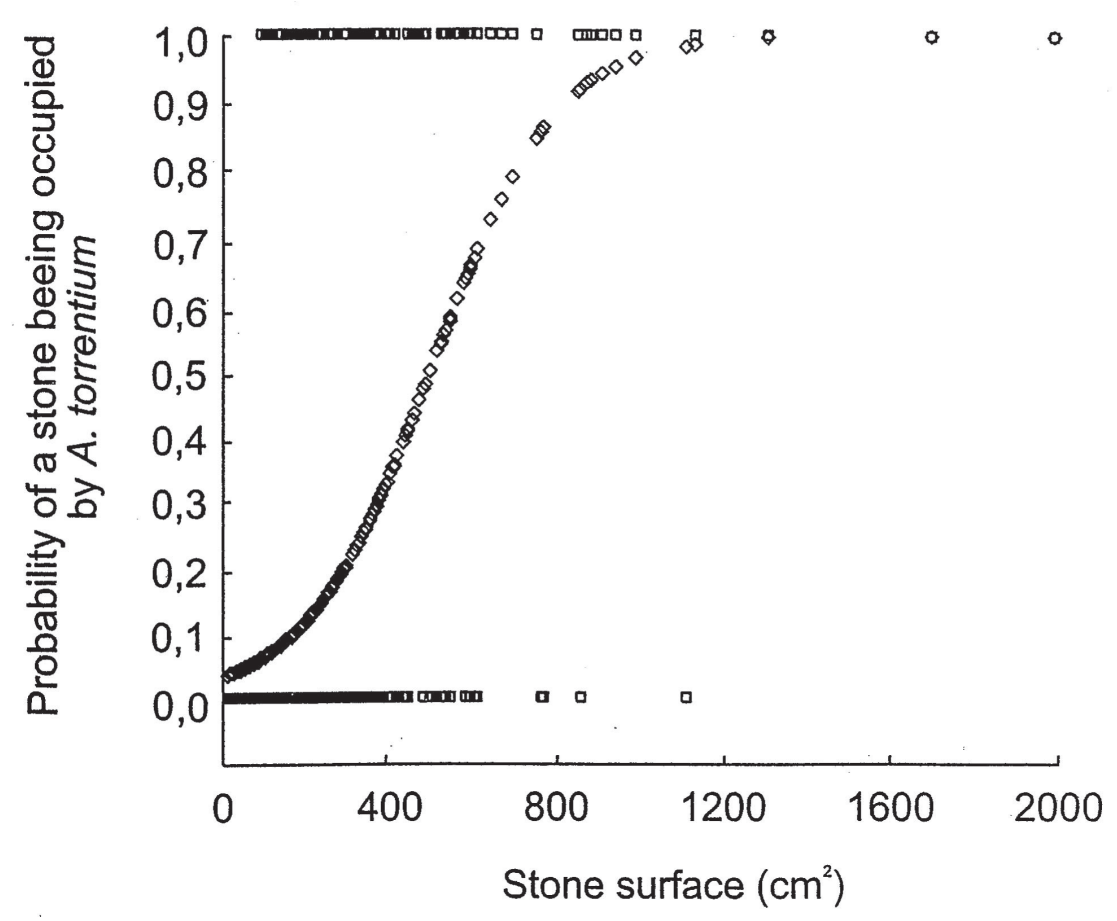

\section{Figure 4}

Logistic regression analysis of stone crayfish presence/absence underneath a stone dependent on stone's bearing surface = stone area (SA) in the Biberbach, Lower Austria. Probability of crayfish presence $=1 / 1+e^{-\left(-3.3601+0.0068^{*} \mathrm{SA}\right)}$. Calculated probabilities $=\diamond$; observed cases $=\square(n=584)$.

Figure 4

Analyse de régression par absence/présence des écrevisses des torrents sous une pierre en fonction de la surface d'appui des pierres (SA) dans le Biberbach, Basse Autriche. Probabilité de présence des écrevisses $=1 / 1+e^{-\left(-3,3601+0,0068^{\star} S A\right)}$. Probabilités calculées $=\diamond ;$ Cas observés $=\square(n=584)$. 


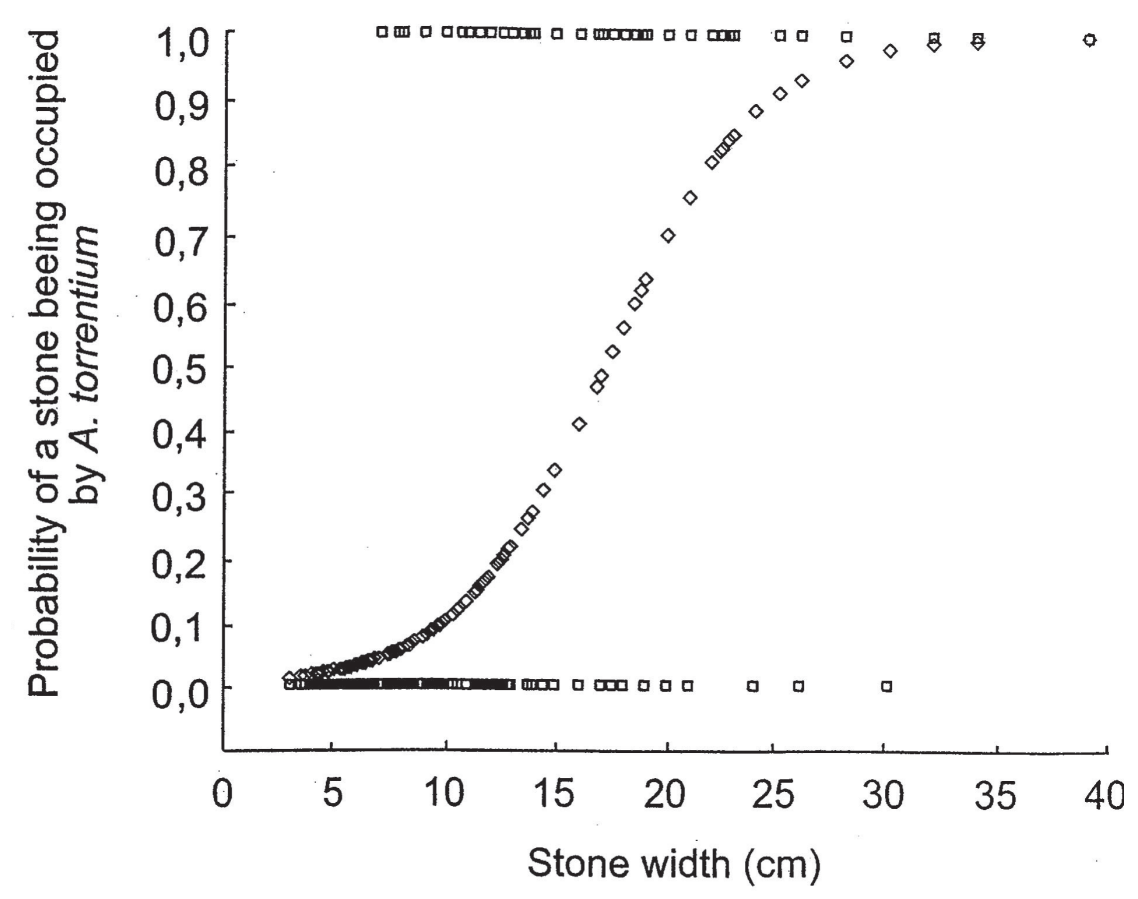

Figure 5

Logistic regression analysis of stone crayfish presence/absence underneath a stone dependent on stone width (SW) in the Biberbach, Lower Austria. Probability of crayfish presence $=1 / 1+e^{-\left(-5.2179+0.3018^{*} S W\right)}$. Calculated probabilities $=\diamond$; observed cases $=\square(n=584)$.

Figure 5

Analyse de régression par absence/présence des écrevisses des torrents sous une pierre et en fonction de sa taille (SW) dans le Biberbach, Basse Autriche. Probabilité de présence des écrevisses $=1 / 1+e^{-\left(-5,2179+0,3018^{*} \mathrm{Sw}\right)}$. Probabilités calculées $=\diamond ;$ Cas observés $=\square(n=584)$.

were found upstream, 82 downstream their last position (Figure 7). Males and females wandered similar distances against the stream flow. There was tendency for the males to travel longer distances in the downstream direction with the currency as opposed to upstream, although this tendency could not be proved to be significant.

Small individuals (TL $<60 \mathrm{~mm})$ were found in similar numbers upstream $(n=30)$ and downstream $(n=33)$ of their last position (Figure 8). The average distances covered in each direction did not significantly differ from each other $(P=0.540)$. A larger number of larger individuals $(T L>60 \mathrm{~mm})$ was found upstream their last position $(n=160)$ than downstream ( $n=127$; Figure 8). The distances covered by the larger individuals were not significantly different from those covered by small individuals.

\section{DISCUSSION}

The presence of $A$. torrentium was mainly determined by water velocity and stone size. Stone crayfish preferred velocities between 0 and $5 \mathrm{~cm} \mathrm{~s}^{-1}$ and avoided shelters in areas with water velocities above $25 \mathrm{~cm} \mathrm{~s}^{-1}$. Studies of KUTKA, RICHARDS and MERRICK, 1996, also showed a negative correlation of current velocity and the abundance of Orconectes propinquus (Girard). They found more young crayfish in shallower waters 


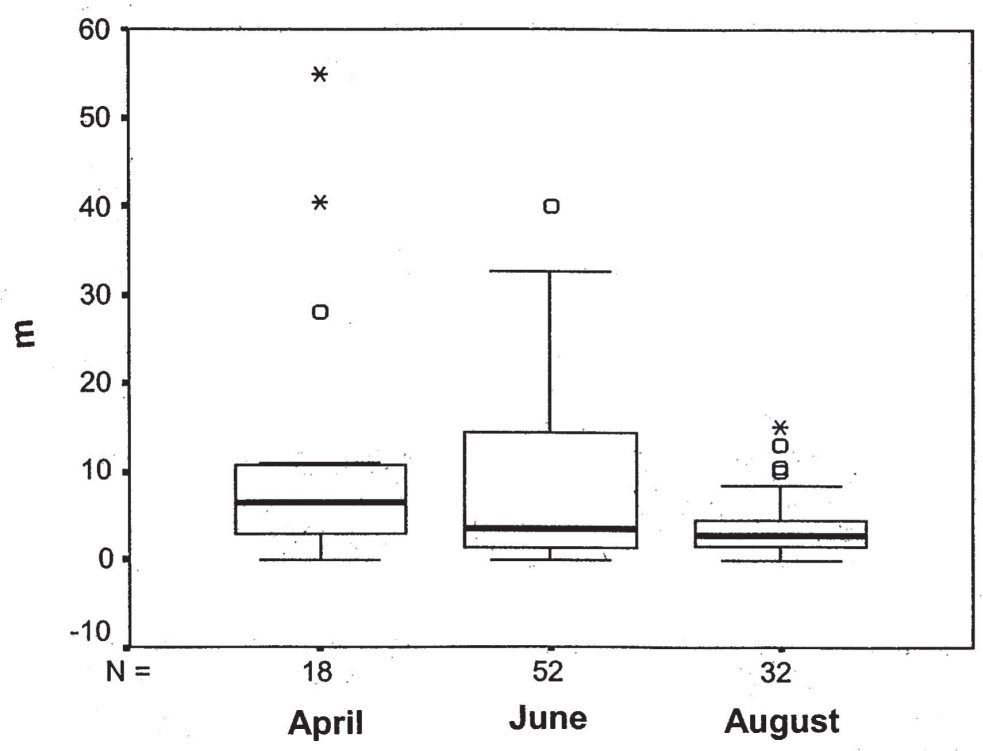

Figure 6

The distances covered by individually marked stone crayfish (A.torrentium) in April, June and August in the study stretch of the Biberbach, Lower Austria, after a time interval from 1 to 3 days since marking.

\section{Figure 6}

Distances couvertes par les individus marqués individuellement (A. torrentium) en avril, juin et août dans la section étudiée du Biberbach, Basse Autriche, pendant les 1 à 3 jours après le marquage.

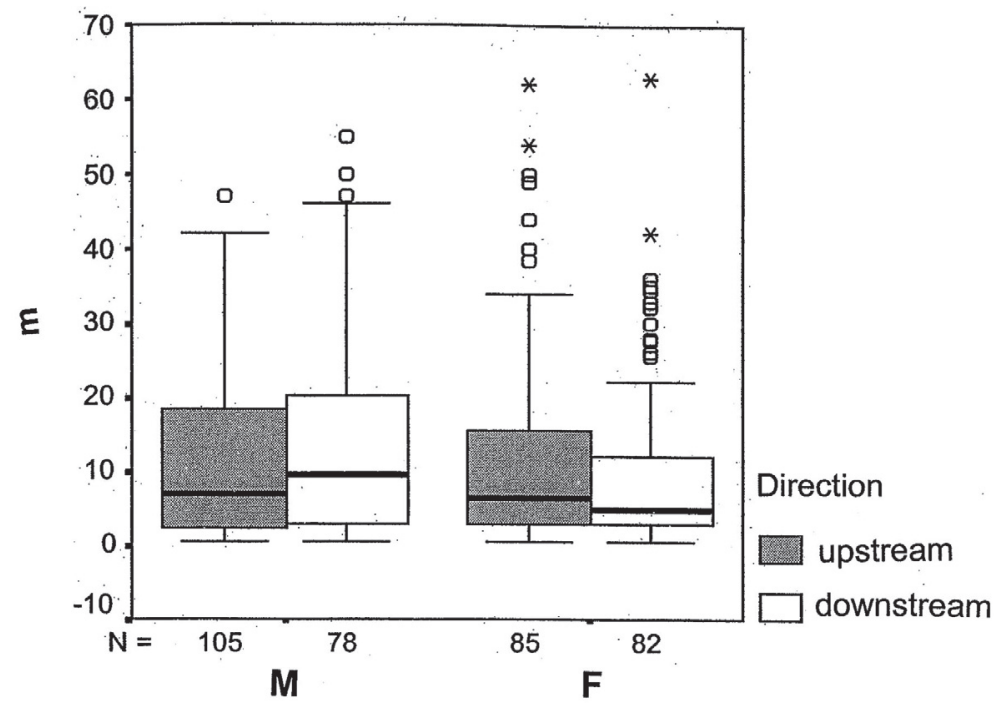

Figure 7

The distances covered by individually marked male (M) and female (F) stone crayfish (A. torrentium) in the study stretch of the Biberbach, Lower Austria, after a time interval of 2 weeks since marking.

Figure 7

Distances couvertes par les individus (A. torrentium), marqués, mâles (M) et femelles (F), dans la section étudiée du Biberbach, Basse Autriche, pendant les 2 semaines après le marquage. 


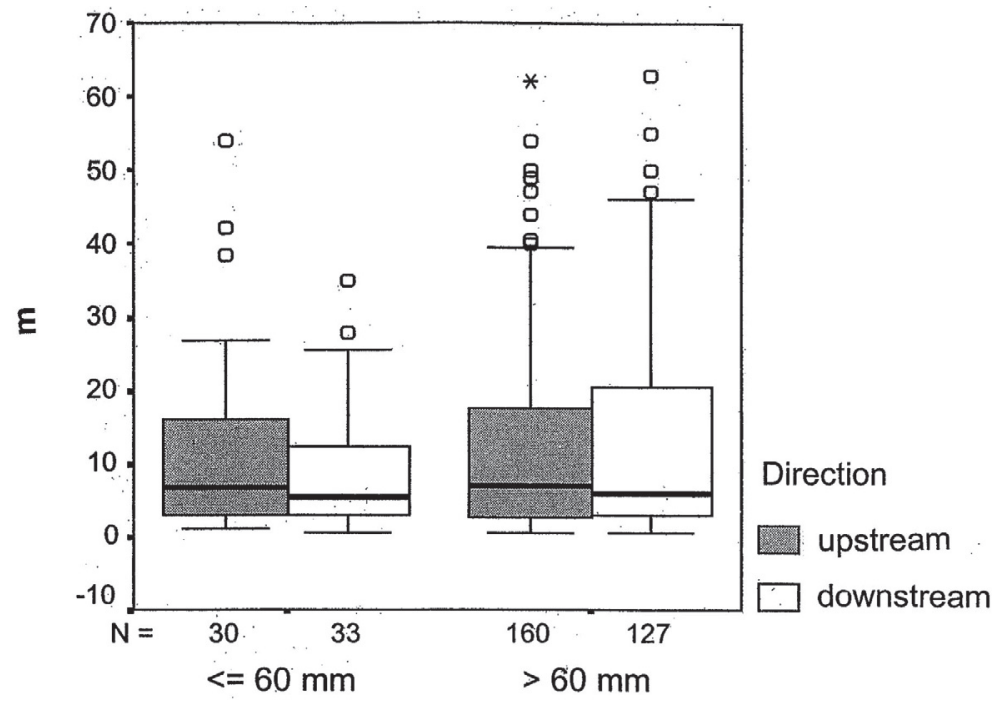

\section{Figure 8}

The distances covered by a group of small $(T L \leq 60 \mathrm{~mm})$ and large $(T L>60 \mathrm{~mm})$ individually marked stone crayfish (A.torrentium) in the study stretch of the Biberbach, Lower Austria, after a time interval of 2 weeks since marking.

\section{Figure 8}

Distances couvertes par un groupe de petits individus (TL $\leq 60 \mathrm{~mm}$ ) et de grands individus ( $T L>60 \mathrm{~mm}$ ) d'écrevisses des torrents (A. torrentium), marqués, dans la section étudiée du Biberbach, Basse Autriche, pendant les 2 semaines après le marquage.

and the results of ENGLUND and KRUPA (2000) suggest that smaller crayfish shift their distributions to shallow water in the presence of predatory fish. Although predatory fish species, the brown trout (Salmo trutta) and the bullhead (Cottus gobio), were observed in the studied section of the Biberbach there was no correlation between water depth and crayfish size. Water depth had no influence on the probability of crayfish presence and is obviously an insignificant shelter variable for A. torrentium. BLAKE and HART (1993) found that the distribution of young Pacifastacus leniusculus (Dana, 1852) was explained by substrate particle size and the presence of predators but not by water depth.

Apart from current velocity, substrate preference influenced distribution and habitat differentiation of four sympatric crayfish species in North Sylamore Creek, Arkansas (PAYNE, 1984). This emphasizes the importance of appropriate shelter to afford crayfish protection from predation and to prevent drift. MASON (1979) tested the relationship between the survival rate of young signal crayfish and shelter availability. The survival rate increased significantly with the number of shelters. Distribution and survival of young signal crayfish in its natural environment was highly dependent on shelters preventing predation from fish (BLAKE and HART, 1993). Crayfish individuals spend time and energy in competition for shelter. LEVENBACH and HAZLETT (1996) used this behaviour to test mechanical and display function of chelae in intraspecific competition of Orconectes virilis. In the study section of the Biberbach, significant positive correlations of crayfish body size and stone size were found for males but not for females. Dominance of crayfish individuals is strongly size-dependent (VORBURGER and RIBI, 1999). This leads to the conclusion that $A$. torrentium males compete for larger stone refuges. VORBURGER and $\mathrm{RIBI}(1999)$ tested interspecific aggressive competition for shelters in $P$. leniusculus and $A$. torrentium. Dominant $A$. torrentium individuals were more persistently aggressive 
and showed higher preference for shelter than dominant $P$. leniusculus individuals. These behavioural differences were explained by a stronger dependence on shelter by A. torrentium. Probably the stone crayfish shows distinct dependence on shelter because it inhabits small brooks characterised by a high gradient. In this environment, crayfish are highly susceptible to drift and terrestrial predators, such as otters and minks. Large stones provide good protection from these threats. As shown in the present study, $A$. torrentium prefer stone-shelters with a bearing surface larger than $300 \mathrm{~cm}^{2}$. The probability of crayfish occurrence rose quickly with increasing stone surface up to $900 \mathrm{~cm}^{2}$. Further increases in stone surfaces failed to increase the probability of crayfish occurrence. Analysis of single stone dimensions showed that stone height had no influence on shelter attractivity. Further we found no correlation of stone height and crayfish size. Investigations on relationships of $A$. pallipes carapace length and refuge size also revealed no correlation of carapace length and stone height, but carapace length was positively correlated with stone area, stone width and stone length (FOSTER, 1993). A stone shape with little difference between length and width fits shelter requirements of $A$. torrentium better than elongated shapes. Stones shorter than 3 times the carapace length and stones less wide than 1.3 times the carapace length are not used as shelters. Similar relations of crayfish body size and stone size are given by FOSTER (1993) for the white-clawed crayfish, A. pallipes. DEMERS, REYNOLDS and CIONI (2004) suggest a partial segregation of habitat use according to crayfish size for A. pallipes in an Irish river, and found that juveniles and smaller crayfish are found in a wider variety of habitats than adults. Authors point to intraspecific competition in different species of crayfish, whereby adults will exclude juveniles from preferred habitats (e.g. STEIN, 1977; LODGE and HILL, 1994). Adult crayfish are thought to reduce growth and survival of juvenile crayfish by competing for shelter and by direct predation, thus inducing smaller crayfish to seek shelter away from adults and cutting the amount of time spent feeding (MOMOT, 1993; BLAKE, NYSTRÖM and HART, 1994; LODGE and HILL, 1994).

The results of this study have implications for further habitat studies and protection measures. If $A$. torrentium is stocked, it is beneficial to ensure that there are suitably sized refuges in areas of low velocity available for the crayfish, including juveniles and small ones. Equally, the effect of canalising and dredging on substrate and water velocity should be controlled to avoid the destruction of prospective habitat requirements of $A$. torrentium. Further measures are needed to enable effective protection of this poorly known and highly endangered species.

The distances wandered by the individually marked stone crayfish in our study stretch of the Biberbach after a time interval from 1 to 3 days varied considerably. The majority, however, changed the position only a couple of meters, and therefore was not highly mobile. Only few specimens covered a distance of up to 55 meters during 24 hours. BOHL (1989) also found that introduced specimens of $A$. torrentium stayed at and near the position of their release. Some $80 \%$ of the introduced stone crayfish were successfully re-captured in the same stretch of the river, even after a time interval of 140 days. In the present study the length of the distance wandered by the individually marked stone crayfish did not increase significantly with time, when comparing 1 to 3 days with two weeks after marking and release. A reason why some of the animals covered a distance in excess of 50 meters after a time interval from 1 to 3 days since marking may be explained by the so-called "fright-response" behaviour that has also been described by ROBINSON, THOM and LUCAS, 2000, for a population of $A$. pallipes. They noticed the widest distances wandered within the first days after catching, handling, marking and releasing the crayfish. This procedure might be too much a disturbance for the animals which are thus disorientated and do not find their way "home". In the Biberbach the distances covered by stone crayfish individuals varied seasonally, being significantly longer in April than in August, and the median for June laying in between the spring and late summer value. This result is in contradiction with the nocturnal activity of the stone 
crayfish. The number of nocturnal active crayfish being observed outside their refuge was considerably higher in August than in April and June. Although activity of stone crayfish markedly increased towards the autumn months, the distances the animals wander were significantly wider during spring, which seemed to be the major dispersal season. This can be the reason why TROSCHEL et al. (1995) trapped a number of stone crayfish in a small brook in Germany during March/April and June/July, but were not successful in trapping them during the reproduction season. In general, there was no clear preference for upstream or downstream movements of $A$. torrentium in the Biberbach, Lower Austria. Comparable results are published for populations of $A$. pallipes by GHERARDI, BARBARESI and VILANELLI, 1998, and ROBINSON, THOM and LUCAS, 2000. KLOSTERMAN and GOLDMAN, 1981, showed that juveniles of signal crayfish, Pacifastacus leniusculus, had a clear preference for upstream movements in the laboratory. This was not the case for juvenile stone crayfish $(T L<60 \mathrm{~mm}$ ) in our study stretch of the Beaver Creek, Lower Austria.

The results of this study have implications for further habitat studies and protection measures in populations of the stone crayfish. Because of the conservative use of space stone crayfish will occupy new territories very slowly - their spreading efficiency is usually very limited. They seem to have a preferred home stone for some time, the size of the refuge stone being highly dependent on the body size of the crayfish. The distances covered from an appropriate home stone is normally within a couple of meters. When re-introduction programmes should be realized the seasonal difference in mobility and the probability of sfright-response" behaviour has to be considered.

In conclusion, our results support strongly that the stone crayfish $A$. torrentium is indicating well good habitat conditions in running waters. In addition to already published parameters, e.g. high oxygen concentration or organic pollution (see FÜREDER and REYNOLDS, 2004)-, the following points are at least typical characteristics of its habitat, but the combination of all is not necessarily required (as there are always exceptions):

- a naturally high substrate heterogeneity (on the beds and banks of upland brooks)

- a high number of appropriate refuge stones (with a bearing area of $>300 \mathrm{~cm}^{2}$ );

- a highly variable flow pattern (preferably $<25 \mathrm{~cm} \mathrm{~s}^{-1}$ );

- a high oxygen concentration (near saturation; LAURENT, 1988; BOHL, 1989; HAGER, 1996);

- natural riparian vegetation: bankside shrubs and trees (eventually deciduous forests): decaying leaf litter as food, and a narrow amplitude in water temperatures: $\angle 20^{\circ} \mathrm{C}$. (If a high oxygen concentration is provided, temperature can be $>20^{\circ} \mathrm{C}$, e.g. outlets of standing waters; PÖCKL, 1998; PEKNY, pers. com.);

- few to moderate organic pollution (upstream villages and intensively used farmland; PÖCKL, 1998).

\section{ACKNOWLEDGMENTS}

We are grateful to Josselin Madec from the University of Poitiers and Madame Valérie Maniglier, chief editor of B.F.P.P., for the French translation. The project was partially funded by the State Government of Lower Austria. FS was in receipt of a University of Vienna studentship. 


\section{REFERENCES}

ABRAHAMSSON S.A., 1965. A method of marking crayfish Astacus astacus (L.) in population studies. Oikos, 16, 228-231.

BLAKE M.A., HART J.B., 1993. Habitat preference and survival of juvenile signal crayfish, Pacifastacus leniusculus - the influence of water depth, substratum, predatory fish and gravid female crayfish. Freshwater Crayfish, 9, 381-384.

BLAKE M.A., NYSTRÖM P., HART P., 1994. The effect of weed cover on juvenile signal crayfish (Pacifastacus leniusculus Dana) exposed to adult crayfish and nonpredatory. Annales Zoologici Fennici, 31, 297-306.

BOHLE., 1989. Ökologische Untersuchungen an ausgewählten Gewässern zur Entwicklung von Zielvorstellungen des Gewässerschutzes. Bayerische Landesanstalt für Wasserforschung, Wielenbach. 237 p.

BUBB D.H., THOM T.J., LUCAS M.C., 2005. The within-catchment invasion of the nonindigenous signal crayfish, Pacifastacus leniusculus (DANA), in upland rivers. Bull. Fr. Pêche Piscic., 376-377, 665-674.

DEMERS A., REYNOLDS J.D., CIONI A., 2004. Habitat preference of different size classes of Austropotamobius pallipes in an Irish River. Bull. Fr. Pêche Piscic., 370-371, 127-137.

ELLENBERG H, 1986. Vegetation Mitteleuropas mit den Alpen in ökologischer Sicht. 4. Auflage. Ulmer, Stuttgart, 989 p.

ENGLUND G., KRUPA J.J., 2000. Habitat use by crayfish in stream pools: influence of predators, depth and body size. Freshwater Biology, 43, 75-83.

EVERSOLE A.G., FOLTZ J.W., 1993 Habitat relationships of two crayfish species in a mountain stream. Freshwater Crayfish, 9, 300-310.

FOSTER J., 1990. Factors influencing the distribution and abundance of the crayfish Austropotamobius pallipes in Wales and the Marches, U.K. Freshwater Crayfish, 8, 78-93.

FOSTER J., 1993. The relationship between refuge size and body size in the crayfish Austropotamobius pallipes (Lereboullet). Freshwater Crayfish, 9, 345-349.

FÜREDER L., REYNOLDS J., 2004. Is Austropotamobius pallipes a good bioindicator? Bull. Fr. Pêche Piscic., 370-371, 157-163.

GAMPERL R., 1990. Vorkommen und Verbreitung von Flusskrebsen (Astacidae) in den Gewässern der Steiermark. PhD Thesis, Univ. Graz, Austria. 120 p.

GHERARDI F., BARBARESI S., VILANELLI F., 1998. Movement patterns of the whiteclawed crayfish, Austropotamobius pallipes, in a Tuscan stream. Journal of Freshwater Ecology, 13, 413-424.

HAGER J., 1996. Edelkrebse: Biologie, Zucht, Bewirtschaftung. Praxisbuch. L. Stocker Verlag. Graz, Suttgart, $128 \mathrm{p}$.

HOSMER D.J., LEMESHOW S., 1989. Applied Logistic Regression. Wiley and Sons, New York, $307 \mathrm{p}$.

JORDAN F., DE LEON C.J., MC CREARY A.C., 1996. Predation, habitat complexity and distribution of the crayfish Procambarus alleni within a wetland habitat mosaic. Wetlands, 4, 452-457.

KLOSTERMAN B.J., GOLDMAN C.R., 1981. Substrate selection behaviour of the crayfish Pacifastacus leniusculus. Freshwater Crayfish, 5, 254-265. 
KUTKA F.J., RICHARDS C., MERRICK G.W., 1996. Habitat relationships and distribution of the crayfish, Orconectes propinquus, in the Saint Louis River Basin, Minnesota, U.S.A. Freshwater Crayfish, 11, 73-82.

LAURENT P.J., 1988. Austropotamobius pallipes and A. torrentium, with observations on their interaction with other species in Europe. In: HOLDICH D.M., LOWERY R.S. (eds) Freshwater Crayfish: Biology, Management and Exploitation. Chapman and Hall, London, 341-364.

LEVENBACH S., HAZLETT B.A., 1996. Habitat displacement and the mechanical and display functions of chelae in crayfish. Journal of Freshwater Ecology, 4, 485-492.

LODGE D.M., HILL A., 1994. Factors governing species composition, population size, and productivity of cool-water crayfishes. Nordic Journal of Freshwater Resources, 69, 111-136.

MACHINO Y., FÜREDER L., 2005, How to find a stone crayfish Austropotamobius torrentium (Schrank, 1803): a note on its biogeography in Europe. Bull. Fr. Pêche Piscic., 376-377, 507-518.

MASON J.C., 1979. Effects of temperature, photoperiod, substrate and shelter on survival, growth and biomass accumulation of juvenile Pacifastacus leniusculus in culture. Freshwater Crayfish, 4, 73-82.

MOMOT W.T., 1993. The role of exploitation in altering the processes regulating crayfish populations. Freshwater Crayfish, 9, 101-117.

NIEMI A., 1977. Population studies on the crayfish Astacus astacus (L.) in the river Pyhäjeki, Finland. Freshwater Crayfish, 3, 81-94.

PAYNE J.F., 1984. Factors influencing patterns of crayfish distribution. Freshwater Crayfish, 7, 100-110.

PÖCKL M., 1998. Verbreitung und Ökologie der in Österreich vorkommenden Flußkrebse. In: Flußkrebse Österreichs (E. EDER and W. HÖDL, eds.). pp. 119-130. Stapfia, 58, zugleich Kataloge des OÖ. Landesmuseums, Neue Folge Nr. 137.

PÖCKL M., 1999. Distribution of crayfish species in Austria with special reference to introduced species. Freshwater Crayfish, 12, 733-750.

PÖCKL M., 2002. Draft program fort he conservation of native crayfish species in Austria. Freshwater Crayfish, 13, 221- 232.

PRETZMANN G., 1994. Rote Liste der Zehnfüßigen Krebse (Decapoda) und Schwebgarnelen (Mysidacea) Österreichs. In: GEPP J. (ed.) Rote Listen gefährdeter Tiere Österreichs. Bundesministerium für Gesundheit und Umweltschutz, Wien. Pp. 279-281.

REYJOL Y., ROQUEPLO C., 2002. Preferential habitat analysis of white-clawed crayfish, notably juveniles, in three brooks of Corrèze, France. Bull. Fr. Pêche Piscic., 367, (4), 741-762.

ROBINSON C.A., THOM T.J., LUCAS M.C. (2000) Ranging behaviour of a large freshwater invertebrate, the white-clawed crayfish Austropotamobius pallipes. Freshwater Biology, 44, 509-521.

SCHULZ N., KIRCHLEHNER W., 1984. Der Steinkrebsbestand Austropotamobius torrentium (Schrank) im Spintikbach (Kärnten, Österreich). Österreichs Fischerei, 37, 47-57.

SMITH G.R.T., LEARNER M.A., SLATER F.M., FOSTER J., 1996. Habitat features important for the conservation of the native crayfish Austropotamobius pallipes in Britain. Biological Conservation, 75, 239-246. 
STEIN R.A., 1977. Selective predation, optimal foraging, and the predator-prey interaction between fish and crayfish. Ecology, 58, 1237-1253.

STREISSL F., 2002. Populationsbiologie, Wachstum und Mobilität des Steinkrebses (Austropotamobius torrentium) in ökomorphologisch unterschiedlichen Abschnitten des Biberbaches, Niederösterreich. PhD Thesis, Univ. Wien, 97 p.

TROSCHEL H.J., 1997. Distribution and ecology of Austropotamobius pallipes in Germany. Bull. Fr. Pêche Piscic., 347, 639-647.

TROSCHEL H.J., DEHUS P., 1993. Distribution of crayfish species in the Federal Republic of Germany, with special reference to Austropotamobius pallipes. Freshwater Crayfish, 9, 390-398.

TROSCHEL H.J., SCHULZ U., BERG R., 1995. Seasonal activity of stone crayfish Austropotamobius torrentium. Freshwater Crayfish, 10, 196.199.

VORBURGER C., RIBI G., 1999. Aggression and competition for shelter between a native and an introduced crayfish in Europe. Freshwater Biology, 42, 111-119.

WHALE R.A., STERNECK R.S., 1992. Habitat restrictions in early benthic life: experiments on habitat selection and in situ predation with the American lobster. Journal of Experimantal Marine Biology and Ecology, 157, 91-114.

WESTIN L., GYDEMO R., 1988. The locomotor activity patterns of juvenile noble crayfish (Astacus astacus) and the effect of shelter availability. Aquaculture, 68, 364-367.

WINTERSTEIGER M., 1985. Flusskrebse in Österreich. Studie zur gegenwärtigen Verbreitung der Flusskrebse in Österreich und zu den Veränderungen ihrer Verbreitung seit dem Ende des 19. Jahrhunderts. Ergebnisse limnologischer und astakologischer Untersuchungen an Krebsgewässern und Krebsbeständen. PhD Thesis, Univ. Salzburg, Austria, $180 \mathrm{p}$. 